Table 8. HARSH-RIGID $\leftrightarrow$ DISINTERESTED-ABDICATING

$\begin{array}{rrrrrr}1 & 2 & 3 & 4 & 5 & \\ 1 & - & 3 & 2 & 15 & \text { Total 21 }\end{array}$

Of the three families with both parents described as 'normal', that is, falling into category 3 , the parents of one family wore preoccupied for the first 9 years of the subject's life with an idiot spastic sibling; and one mother was described by the classifying school as having given no moral training. The third mother suffers from psychotic opisodes. One father is psychotic.

of the fathers $36(20.8$ per cent) were unemployed; 45 (26.0 per cent) were delinquent (convicted); 9 (5.0 per cent) were delinquent and unemployed. Of the 168 mothers for whom full information was available $9(5 \cdot 3$ per cent) were delinquent. Of the 173 families 74 (42 per cent) had more than one delinquent child. For this group of 173 boys the protection test gave the following family dominance pattern:

At the top of the circlo:

$$
\begin{array}{cccccc}
\text { F. } & \text { M. } & \text { Br. } & \text { Sis. } & \text { Self/other } & \\
42 & 72 & 39 & 13 & 7 & 173
\end{array}
$$

The pattern in cases with fathers delinquent was:

\begin{tabular}{cccccc}
\multicolumn{5}{c}{ Table 10} \\
F. & M. & Br. & Sis. & Self/other \\
12 & 22 & 6 & 4 & 1 & 45
\end{tabular}

and the pattern where siblings were also delinquent but father non-delinquent:

$$
\begin{array}{ccrrcr}
\multicolumn{6}{c}{\text { Table 11 }} \\
\text { F. } & \text { M. } & \text { Br. } & \text { Sis. } & \text { Self/other } \\
17 & 29 & 23 & \mathbf{4} & \mathbf{1} & \mathbf{7 4}
\end{array}
$$

The records of 53 girls of $11-15$ years committed to approved schools, while far less detailed and comprehensive than those for the boys, were examined in the same manner.

Of this group 25 came from broken or incomplete families, fathers being absent in 15 cases, mothers in 5 cases; the information available was inadequate in 5 cases.
Of the 28 girls from intact families who were studied, reports on parental attitudes yielded the following information:

Table 12. Fathers' Reported Attitude to the Family

$\begin{array}{rrrrr}1 & 2 & 3 & 4 & 5 \\ 5 & 7 & - & 3 & 13\end{array}$

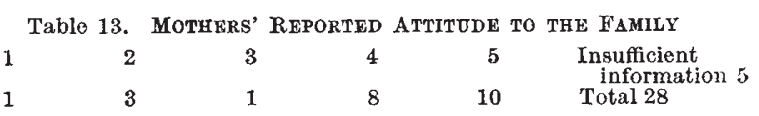

Of the fathers, 5 were unemployed; 5 wero delinquent; 1 was delinquent and unomployed. Of the mothers, 5 were delinquent.

The attitudes adopted by parents of delinquents of both sexes seem from this small sample of girls to be vory similar. However, mothers rarely exhibit to their daughters the overprotective attitude they often show towards their sons.

No evidence was forthcoming to suggest that early separation from the mother was a significant factor in the delinquency of either sex or that the quality of the discipline and control of the mother alone as suggested by Glueck ${ }^{2}$ was of first importance.

$\mathrm{Mead}^{3}$, as long ago as 1950 , affirmed that the cohesion of society depends on the learned nurturing behaviour of the human male. It soems clear from this present research that both parents are important in the socialization of the child but that the role of the father is more vital than has hitherto been admitted. The father who chooses to abdicate or to dominate rather than to nurture or who, because of the defects in his own rearing, is incapable of learning to nurture adds to the difficulties of his children's socialization and appears from the investigation so far carried out to be responsible in a largo moasure for his children's social deviation.

\& Bradley, J., Nature, 200, 455 (1963).

2 Glueck, Sheldon and Eleanor, Family Environment and Delinquenoy (Routledge, Kegan Paul, 1962).

${ }^{3}$ Mead, Margaret, Male and Female (Gollancz. 1950).

\title{
THE TROPICAL PRODUCTS INSTITUTE
}

$I^{\mathrm{N}}$ his report for $1963 *$, the director of the Tropical Products Institute, Mr. E. S. Hiscocks, states that investigations of aflatoxin and its presence in groundnuts and other materials remained the major project throughout the year, although by the end of the year the results of this work allowed all but a small nucleus of staff to return to other duties. The Institute is, however, still providing advice to most parts of the world on the problem and is maintaining close contact with other laboratories working in this field. In September, a member of the staff was seconded to Nigeria for six months to assist with work on tosting samples for aflatoxin and to train local staff in this techniquo. In October, the Instituto acted as host to an international meeting organized by the United Nations International Childron's Emergency Fund on the subject of allatoxin.

Two new projects were started during the yoar. The first, which arose from a growing concern about the widespread use of toxic insecticides and the concomitant problems of insect resistance and toxic residues, deals with a search for insect attractants. It is hoped that the use of such attractants, which may operate through sexual, food or ovipositional stimuli, may provide alternative methods of controlling certain tropical insects and may also overcome the problem of insect resistance to insecticides.

* Department of Scientific and Industrial Research. Report of the Tropical Products Institute 1963: The Report of the Tropical Products Institute Committee with the Report of the Director of the Tropical Products Institute. Pp. vi +33. (London: H.M.S.O., 1964.) 38. net.
The second is an investigation of methods for local processing of tropical products with the view of improving the oquipment or method, or of designing machinery where this does not exist. The first investigation, which was recently started, is concerned with the difficult problem of cashew nut decortication.

During the year, 838 enquiries were received from 78 countries and international bodies. This represents a slight decrease on the previous year which can prob. ably be explained by the setting up of similar laboratories in various developing countries. Although such laboratories will eventually be able to take over much of the work that the Institute has carried out in the past, it means that the enquiries now received tend to come from such laboratories and concern aspects of work for which they do not have facilities. Thus, the enquiries received, although diminishing somewhat in number, tend to incroase in complexity.

Among the many important investigations referred to in the report is one concerned with dried fish. The methods of drying used in the tropies are usually very primitive: the fish is laid out in the sun! or placed over an open fire, and it is probable that these methods not only impair the quality of the fish but also reduce the biological value of the protein. A detailed investigation of dried fish from tropical countries has been carried out and a series of experiments was aimed at investigating the drying of fish under conditions approximating those which prevail in 
both dry and humid tropical climates. The experiments were undertaken in a small Torry kiln in which tropical conditions were simulated.

Even in dry tropical climates, fish drying can normally be carried out for only $8 \mathrm{~h}$ a day because at sundown the temperature falls and the humidity increases. An attempt was made to determine whether hanging, stacking or pressing fish overnight gave the shortest drying time. The results of these experiments indicated that there might be some advantage in pressing during the later stages of drying, thus enabling the moisture to equilibrate. Further work with more refined apparatus will bo required before definite conclusions can be drawn.

The 'available lysine' contents of threo specimens of Tilapia nilotica from Uganda were determined by Carpenter's method in order to ascertain if any damage had been caused by the different methods of drying. The three specimens had been either fresh-frozen, or sun-dried, or fresh-frozen and later dried in a Torry kiln. It was found that the fresh-frozen fish contained most available lysine $(10.7 \mathrm{~g} / 16 \mathrm{~g}$ nitrogen) as would be expected, the sun-dried fish contained least $(6 \cdot 1 \mathrm{~g} / 16 \mathrm{~g}$ nitrogen) and the kiln-dried fish gave an intermediate value $(6 \cdot 9 \mathrm{~g} / 16 \mathrm{~g}$ nitrogen). Those concerned with this aspect of the Institute's work were surprised to find that the loss of available lysine in sun-drying was as great as that occurring in the manufacture of fish meal where much highor temperatures are used. However, as only three fish wero used in the experiments the results were not, at the time of preparing the report, regarded as conclusive. They indicated, however, that further work on these lines would be worthwhile. Factors, other than protein deterioration, which are important in tho nutritive value of fish, have not been examined as part of this investigation.
An officer was seconded to the Government of Aden during October 1962-March 1963 to investigate the problems involved in preparing dried fish for export. A survey of the curing methods in present-day use in Aden suggested that minor improvements in technique would enable the processors to make much better products. A series of fish-curing experiments was carried out and the crew of a Fisheries Department vessel was trained to demonstrate the methods evolved to local fishermen. These demonstrations included dry-salting in closed vessols instead of salting in open kench piles, proper washing of tho fish using brine, and drying on raised racks in the shade instead of throwing the fish on the sand in the open sun. The success of these methods was illustrated by the fact that products made by the demonstrators fetched higher prices than the traditional products in local markets. Two fish-curing stations wore designed for experimental use and built so that the experiments and demonstrations could be continued after the officers' departure.

The problem of insect infestation in Aden of dried fish during preparation and in storage was also examined. Early in the assignment it became obvious that this was a serious problem. A preliminary report on insect infestation was, therefore, prepared and forwarded to the Department of Technical Co-oporation, since it was obvious that insect infestation should be investigated by an entomologist specializing in stored products.

The report recommends that domonstration of the improved curing methods should continue, that samples of the products made should be sent to overseas markets for evaluation and that experiments with species of fish at present under-exploited should continue. It is also recommended that the possibility should be investigated of erecting commercial fish-curing stations for communal use.

\section{ROYAL INSTITUTE OF TECHNOLOGY, STOCKHOLM}

$\mathrm{P}$ ROF. H. ERDTMAN, of tho Kungliga Tekniska Högskolan, Stockholm, has provided an intoresting account of the Royal Institute of Technology, Stockholm, which was founded in 1827 as a 'humble' school of technology (May and Baker Bulletin, 6, No. 2; May 1964). The staff of the Institute then consisted of one director, two professors, two other toachers and eight other employees, including one steward and one porter. Instruction was in the fundamental subjects of "general natural knowledge, i.e., physics and chemistry, with particular reference to those of the goneral laws of Nature that find their most common applications in industry", and it was required to be "popular and practical rather than strictly scientific". In 1876 the Institute was transformed into an institute of technology, but in 1907 it still had only two professors of chemistry, ono in 'technical chemistry' and one in 'general chemistry'. The present Kungliga Tekniska Högskolan, has nine departments and about eighty professors. There are about 750 other employees, of whom some 500 are teaching and research assistants, and in all about 4,000 studonts.

The Department of Chemistry now has twelve professors and three other senior lecturers, each in charge of his own branch of study: analytical chemistry, inorganic chemistry, organic chemistry, nuclear chemistry, physical chemistry, wood chemistry, chemical technology, polymer technology, paper technology, collulose technology, food chomistry (biochemistry), fermentation chemistry, applied electro-chemistry and corrosion, heat technology, and chemical engineering equipment.

The degrees awarded by the Institute include civilingenjor, teknologie licentiat, and teknologie doktor. Tho time normally required for the first degree is four years, although in practice $4 \cdot 5-5$ years are often needed. 'The licentiate takes a further two or three yoars, and the doctorate yet another two or throo or even longer. The licentiate corresponds roughly to an American, British or German $\mathrm{Ph} \mathrm{D}$., and the doctorate approximates to a British D.Se.

Students enter the Institute of Technology at the age of eighteen to twenty, and, owing to compulsory military service, malo students are about twenty-five when they pass their civilingenjorsexamen. Approximately soventy freshmen are admitted annually to the Department of Chemistry, of whom about 10 per cent are women. Admission is compotitive and far more students apply for admission than there are places. During the first two years, basic subjects are studied, for example, mathematics, physics, inorganic and organic chemistry, machine element design, and mechanies. The first courses in chomistry aro elomentary 'general courses', and all firstand second-year courses must be completed before starting the third-year course. During this and the fourth year, applied subjects are studied, and more advanced chomistry courses are available, but these are compulsory only for students who have chosen the relevant field of spocialization. During the fourth year, specialization is much more intensive. Finally, for the civilingenjorsexamen, the student must carry out a small research project, roquiring about three months work; about four months of practical experioneo in industry is also required.

Every student who has obtained a civilingenjor's degree may continue his studies for the licentiate and then go on to seek the degree of teknologie doktor. Foreign students who can show that they have taken a degree comparable to that of civilingenjor may be admitted to study for the licentiate and then for the doctor's degree by special 